\title{
Aminoborohydrides. 13. facile reduction of $N$-alkyl lactams with 9- borabicyclo[3.3.1]nonane (9-BBN) and lithium aminoborohydrides (LAB) reagents
}

\author{
Christopher J. Collins $\dagger$ and Bakthan Singaram* \\ †Department of Pharmaceutical Chemistry, University of California at San Francisco, San \\ Francisco, CA 94143-0446 \\ E-mail:collinc@itsa.ucsf.edu \\ *Department of Chemistry, University of California at Santa Cruz, Santa Cruz, CA 95064 \\ E-mail: singaram@chemistry.ucsc.edu
}

\section{Dedicated to Prof. Alfred Hassner on the occasion of his $70^{\text {th }}$ birthday}

(received 16 Mar 01; accepted 15 Oct 01; published on the web 23 Oct 01)

\begin{abstract}
Two methods to reduce $\mathrm{N}$-alkyl lactams to the corresponding cyclic amines using 9borabicyclo[3.3.1] nonane (9-BBN) and lithium aminoborohydride (LAB) reagents are reported. The lactam reductions required 2.2 molar equivalents of 9-BBN or 1.5 molar equivalents of LAB reagent and were complete within two hours in refluxing THF $\left(65^{\circ} \mathrm{C}\right)$. Reductions with these reagents are chemoselective and complementary in nature. A lactam can be reduced in the presence of an ester with 9BBN. At lowered temperature, an ester can be reduced in the presence of lactam with LAB reagents. At elevated temperature, LAB reagents act as powerful reducing agents, and reduce both lactam and ester functional groups in a difunctional molecule. The reaction products were easily isolated in good to excellent yields after simple work-ups.
\end{abstract}

Keywords: Lactams, reduction, amines, 9-borabicyclo[3.3.1]nonane, lithium aminoborohydrides

\section{Introduction}

The reduction of lactams to the corresponding cyclic amines is an important transformation in the synthesis of biologically active plant alkaloids and pharmaceutical compounds. ${ }^{1}$ Many reagents are available for the reduction of lactams to amines including diisobutylaluminum hydride, ${ }^{2}$ alane, ${ }^{3}$ sodium bis(2-methoxyethoxy)aluminum hydride, ${ }^{4}$ rhodium-catalyzed hydrosilylation, ${ }^{5}$ and sodium borohydride, ${ }^{6}$ lithium aluminum hydride $\left(\mathrm{LiAlH}_{4}\right)^{7}$ and boranetetrahydrofuran $\left(\mathrm{BH}_{3}-\mathrm{THF}\right){ }^{8}$ Of these reagents, $\mathrm{LiAlH}_{4}$ and $\mathrm{BH}_{3}$-THF have been two of the most commonly used reagents for the reduction of lactams in the literature. However, both of these 
reagents have some serious drawbacks. Both $\mathrm{LiAlH}_{4}$ and $\mathrm{BH}_{3}$-THF are highly pyrophoric reagents. ${ }^{9}$ In addition, $\mathrm{LiAlH}_{4}$ tends to form strong emulsions during the aqueous work-up due to the formation of aluminum oxides. An excess of the expensive borane reagent is required for complete substrate reduction due to the strong complexation of $\mathrm{BH}_{3}$ to the amine products.

We were interested in developing new methods for lactam reduction using easy to handle reagents such as 9-borabicyclo[3.3.1]nonane (9-BBN) and lithium aminoborohydride (LAB) reagents. Lithium aminoborohydrides are a new, powerful, selective and non-pyrophoric class of reducing agents. Lithium aminoborohydrides are able to reproduce in air virtually all of the transformations now carried out with $\mathrm{LiAlH}_{4}$ including the reduction of amides and lactams. ${ }^{10}$ 9Borabicyclo[3.3.1]nonane is a regioselective hydroboration agent and chemoselective reducing agent for the reduction of aldehydes, ketones, acid chlorides, amides and lactams. ${ }^{11}$ Herein we report the results of our comparative study on the reduction of lactams with these reagents.

\section{Results and Discussion}

\section{Reduction of lactams with 9-borabicyclo[3.3.1]nonane}

In our study, we investigated the reduction of 5-and 6-membered $N$-alkyl lactams using 9-BBN as the reducing agent. Half molar $(0.5 \mathrm{M})$ solutions of $9-\mathrm{BBN}$ in tetrahydrofuran (THF) were prepared by quickly weighing out a calculated amount of commercial 9-BBN crystals in air and dissolving the reagent in anhydrous THF. Initially, when only a theoretical amount of 9-BBN (2.0 molar equivalents) was used and/or the reductions were attempted at room temperature $\left(25^{\circ} \mathrm{C}\right)$, a mixture of amine product and unreduced substrate was isolated. We then employed a slight excess of 9-BBN (2.2 molar equivalents) reagent and carried out the reductions in refluxing THF $\left(65^{\circ} \mathrm{C}\right)$ to insure complete and rapid reduction of the lactam substrates. 1-Benzylpyrrolidin-2-one was refluxed in THF with 2.2 molar equivalents of 9-BBN and the reaction was monitored by ${ }^{11}$ B-NMR and FTIR spectroscopy. At $1 \mathrm{~h}$, the characteristic 9-BBN singlet at $\delta=$ $+27 \mathrm{ppm}$ was absent from the ${ }^{11} \mathrm{~B}-\mathrm{NMR}$ spectra and the lactam carbonyl peak $\left(v=1659 \mathrm{~cm}^{-1}\right)$ had disappeared from the FTIR spectra. After a simple non-oxidative work-up with ethanolamine in pentane to separate the amine product from the 9-BBN by-product, 1-benzyl-pyrrolidine (1) was isolated in very high yield as the sole reduction product as determined by ${ }^{1} \mathrm{H}-\mathrm{NMR},{ }^{13} \mathrm{C}$ NMR and HRMS analysis (eq 1).
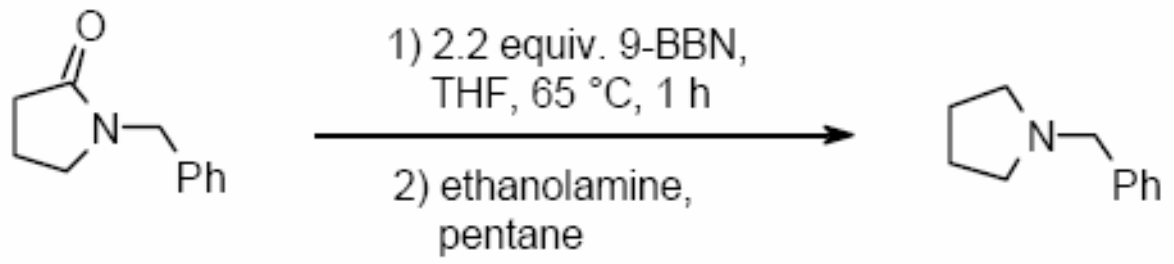
Encouraged by our initial results with 1-benzyl-pyrrolidin-2-one, we examined the reduction of 1-phenyl-pyrrolidin-2-one with 9-BBN. After refluxing the lactam substrate in THF for $1 \mathrm{~h}$ with 9-BBN, 1-phenyl-pyrrolidine (2) was obtained in essentially quantitative yield (Table 1, Entry 2). The reduction of 1-cyclohexyl-pyrrolidin-2-one containing a moderately sterically bulky $N$-alkyl group with 9 -BBN also gave a good yield of the amine product. The reduction of this substrate required only 2.2 molar equivalents of 9-BBN and was complete within $1 \mathrm{~h}$ by ${ }^{11} \mathrm{~B}-$ NMR analysis of a reaction aliquot. The cyclic amine product, 1-cyclohexyl-pyrrolidine (3), was isolated from the reaction mixture in $82 \%$ yield (Table 1, Entry 3). Very high isolated yields were obtained from the reduction of high molecular weight lactams with 9-BBN. These results indicated that the lactam substrates were completely converted to the amine products using 9BBN. When 1-octyl-pyrrolidin-2-one was added to a $0.5 \mathrm{M} 9-\mathrm{BBN}$ solution in THF and the resulting solution was refluxed for $1 \mathrm{~h}, 1$-octyl-pyrrolidine (4) was obtained from the reduction in $93 \%$ isolated yield (Table 1, Entry 4). 1-Dodecyl-pyrrolidin-2-one was completely reduced in refluxing THF using 9-BBN. 1-Dodecyl-pyrrolidine (5) was isolated from this reaction in $97 \%$ yield (Table 1, Entry 5). The reduction of the bicyclic lactam, (3S-cis)-(+)-3-isopropyl-7amethyl-tetrahydro-pyrrolo[2,1-b]oxazol-5-one, required 3.2 molar equivalents 9-BBN and refluxing in THF for $2 \mathrm{~h}$ for complete consumption of the 9-BBN reagent. Careful analysis of the crude isolated material by ${ }^{1} \mathrm{HNMR}$ indicated that the reaction had given a mixture of two products, a bicyclic amine and an amino alcohol, (+)-3-methyl-2-(2-methyl-pyrrolidin-1-yl)butan-1-ol (6), similar to the one obtained by Meyers. ${ }^{11 \mathrm{c}, \mathrm{d}}$ The major product 6 was isolated in $54 \%$ yield after column chromatography (Table 1, Entry 6). The reduction of a secondary lactam, oxindole, with 9-BBN resulted in the isolation of an aromatic amine product, indole (7). The reduction of this substrate required 1.1 molar equivalents of 9-BBN and resulted in an $80 \%$ isolated yield of 7 (Table 1, Entry 7). 9-Borabicyclo[3.3.1]nonane was able to reduce this lactam in manner similar to $\mathrm{BH}_{3}$-THF. ${ }^{7 \mathrm{a}}$ 
Table 1. Reduction of lactams with 9-BBN

Entry

${ }^{a}$ All reactions carried out on a $10 \mathrm{mmol}$ scale unless otherwise noted. ${ }^{\mathrm{b}}$ Isolated yields. ${ }^{\mathrm{c}}$ All compounds were characterized by ${ }^{1} \mathrm{H}-\mathrm{NMR},{ }^{13} \mathrm{C}-\mathrm{NMR}$ and HRMS. ${ }^{\mathrm{d}} 5 \mathrm{mmol}$ scale reaction.

Two 6-membered $N$-alkyl lactams were completely reduced by 9 -BBN and corresponding cyclic amine products were obtained in high yields. 1-Methyl-3, 4-dihydro- $1 H$-quinol-2-one was completely reduced by 9-BBN within $1 \mathrm{~h}$ at $65^{\circ} \mathrm{C}$. The amine product, 1-methyl-1, 2, 3, 4tetrahydro-quinoline (8), was obtained in $86 \%$ isolated yield (Table 1, Entry 8 ). The reduction of 
4-methyl-4H-1, 4-benzo[1,4] oxazin-3-one with 2.2 molar equivalents of 9-BBN resulted in the isolation of 4-methyl-3, 4-dihydro-2H-benzo[1, 4]oxazine (9) in $93 \%$ isolated yield (Table 1 , Entry 9). The results of this lactam reduction study using 9-BBN are summarized in Table 1.

After studying the reduction of lactams with $9-\mathrm{BBN}$, we turned our attention towards the reduction of lactams with $\mathrm{LAB}$ reagents.

\section{Reduction of lactams with lithium aminoborohydrides}

Initially, we postulated that LAB reagents would be able to perform a selective reduction of $N$ alkyl lactams to give either a cyclic amine or an amino alcohol, which would be similar to the selective reduction of tertiary amides using the LAB reagents. ${ }^{10 a, b}$ However, reduction of $N$-alkyl lactams with LAB reagents gave only the corresponding cyclic amine products, regardless of the steric requirements of the amino group contained in the LAB reagent. The reduction of 1-benzylpyrrolidin-2-one using $\quad 1.5$ molar equivalents of $\mathrm{LiH}_{3} \mathrm{BNMe}_{2}$ gave 1 in $86 \%$ isolated yield. In a similar manner, the reduction of 1-benzylpyrrolidin-2-one with the sterically more demanding $\mathrm{LiH}_{3} \mathrm{BN}(i-\mathrm{Pr})_{2}$ also gave $\mathbf{1}$ in $86 \%$ isolated yield (eq 2).
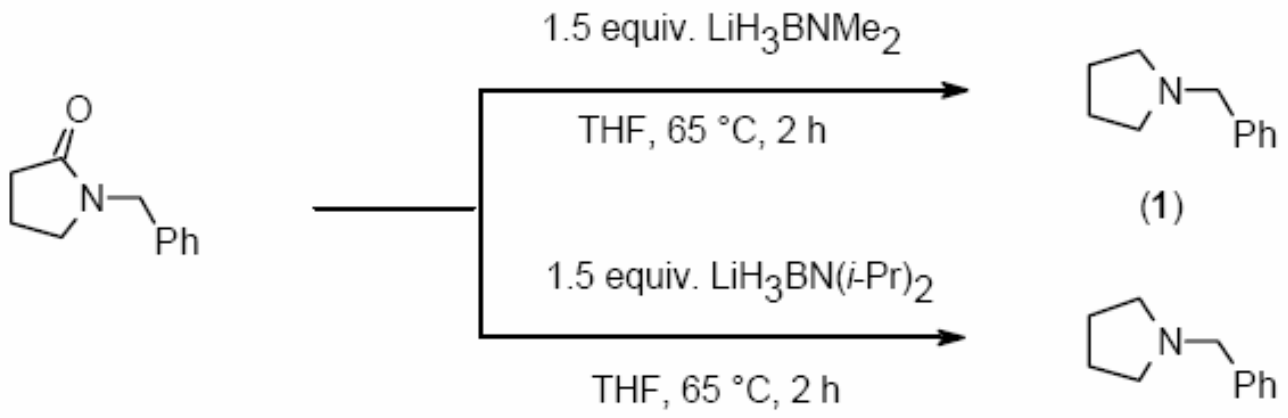

(1)

THF, $65^{\circ} \mathrm{C}, 2 \mathrm{~h}$

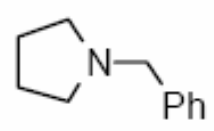

\section{Equation 2}

The reduction of 1-benzylpyrrolidin-2-one was carried out by adding the neat lactam substrate to a $1 \mathrm{M}$ solution of LAB reagent in THF and heating the reaction to reflux $\left(65^{\circ} \mathrm{C}\right)$. The reduction of 1-benzyl-pyrrolidin-2-one in refluxing THF using only one molar equivalent of $\mathrm{LiH}_{3} \mathrm{BNMe}_{2}$ gave 1 and some unreacted starting material. Therefore, 1.5 molar equivalents of LAB reagent were subsequently used per mole of substrate to insure rapid and complete reduction of the lactam functional group. The lactam reduction was easily monitored by FTIR spectroscopy for the disappearance of the characteristic lactam carbonyl peak of 1-benzylpyrrolidin-2-one at $v=1659 \mathrm{~cm}^{-1}$. Upon completion of the reduction, the amine product 1 was easily isolated after a simple aqueous work-up.

The reduction of a lactam containing a moderately sterically bulky $N$-alkyl group with $\mathrm{LiH}_{3} \mathrm{BNMe}_{2}$ gave a good yield of the amine product. The reduction of 1-cyclohexyl-pyrrolidin- 
2-one using 1.5 molar equivalents of $\mathrm{LiH}_{3} \mathrm{BNMe}_{2}$ gave 2 in $80 \%$ isolated yield (Table 2, Entry 2).

Reduction of high molecular weight lactams with $\mathrm{LiH}_{3} \mathrm{BNMe}_{2}$ gave high yields of the amine products indicating that $\mathrm{LiH}_{3} \mathrm{BNMe}_{2}$ completely reduced the lactam substrates. When 1-octylpyrrolidin-2-one was refluxed in THF for $2 \mathrm{~h}$ with $\mathrm{LiH}_{3} \mathrm{BNMe}_{2}$, compound 4 was isolated from the reaction mixture in $89 \%$ isolated yield (Table 2, Example 3). The reduction of 1-dodecylpyrrolidin-2-one with $\mathrm{LiH}_{3} \mathrm{BNMe}_{2}$ gave 5 in $96 \%$ yield (Table 2, Entry 4). The progress of the lactam reductions with $\mathrm{LAB}$ reagents was easily monitored by FTIR spectroscopy for the disappearance of the lactam carbonyl peaks for the 5-and 6-membered $N$-alkyl lactams at $v=$ $1705-1660 \mathrm{~cm}^{-1}$. Most of the reductions with LAB reagents were essentially complete after refluxing in THF for $2 \mathrm{~h}$ and the amine products were easily isolated after a simple aqueous work-up.

Lithium dimethylaminoborohydride was not able to reduce the secondary lactam, oxindole. When oxindole was added to a $1 \mathrm{M}$ THF solution of $\mathrm{LiH}_{3} \mathrm{BNMe}_{2}$, an exothermic reaction ensued and a white solid precipitated out of solution. The lactam carbonyl peak at $v=1732 \mathrm{~cm}^{-1}$ decreased over a $2 \mathrm{~h}$ reaction period. After $2 \mathrm{~h}$, the reaction was quenched with deuterium oxide $\left(\mathrm{D}_{2} \mathrm{O}\right)$, and then $3 \mathrm{M} \mathrm{HCl}$ was added. After extracting the reaction mixture with ether, the starting material was recovered in $85 \%$ yield (Table 2, Example 5). In this example, $\mathrm{LiH}_{3} \mathrm{BNMe}_{2}$ may have acted as a lithium amide base. The acidic nitrogen proton $(\mathrm{pKa} \sim 15)$ of the lactam was possibly deprotonated by $\mathrm{LiH}_{3} \mathrm{BNMe}_{2}$ resulting in a THF-insoluble lithium salt of oxindole, that was not reduced by the remaining LAB reagent. However, this hypothesis was not confirmed by deuterium incorporation into the recovered starting material.

The reduction of two 6-membered $N$-alkyl lactams with $\mathrm{LiH}_{3} \mathrm{BNMe}_{2}$ gave high yields of the corresponding amines. The reduction of 1-methyl-3, 4-dihydro-1H-quinolin-2-one with 1.5 molar equivalents of $\mathrm{LiH}_{3} \mathrm{BNMe}_{2}$ gave 8 in $96 \%$ yield (Table 2, Entry 6). The reduction of 4methyl-4H-benzo[1, 4] oxazin-3-one with $\mathrm{LiH}_{3} \mathrm{BNMe}_{2}$ gave 9 in $75 \%$ yield (Table 2, Entry 7). The results of our lactam reduction study using LAB reagents are summarized in Table 2. 
Table 2. Reduction of lactams with lithium dimethylaminoborohydride

Entry

${ }^{a}$ All reactions carried out on a $10 \mathrm{mmol}$ scale unless otherwise noted. ${ }^{\mathrm{b}}$ Isolated yields. ${ }^{\mathrm{c}}$ All compounds were characterized by ${ }^{1} \mathrm{H}-\mathrm{NMR},{ }^{13} \mathrm{C}-\mathrm{NMR}$ and HRMS. ${ }^{\mathrm{d}} 5$ mmol scale reaction. ${ }^{\mathrm{e}}$ Recovered yield of starting material.

Most $N$-alkyl lactams were effectively and exclusively reduced to the corresponding cyclic amine products by LAB reagents. However, there are caveats for these reductions. One $N$-alkyl lactam substrate underwent ring-opening with the LAB reagents to give some of an amino alcohol product. Reduction of 1-phenyl-pyrrolidin-2-one at $25{ }^{\circ} \mathrm{C}$ with $\mathrm{LiH}_{3} \mathrm{BNMe}_{2}$ gave a mixture of 1-phenyl-pyrrolidine (2) (68\% by GC) and 4-phenylamino-butan-1-ol (10) (32\% by GC) in $85 \%$ yield (Table 3, Example 1). Subsequent reduction of this substrate at $25{ }^{\circ} \mathrm{C}$ with a LAB reagent that contained a sterically hindered amino group did not seem to significantly change the product ratio. The reduction of 1-phenyl-pyrrolidin-2-one with $\mathrm{LiH}_{3} \mathrm{BN}(\mathrm{i}-\mathrm{Pr})_{2}$ at 
$25{ }^{\circ} \mathrm{C}$ gave 2 (60\% by GC) and 10 (40\% by GC) in $95 \%$ yield (Table 1, Example 2). At elevated temperature, the reduction of 1-phenyl-pyrrolidin-2-one gave even higher amounts of the amino alcohol product. At $65{ }^{\circ} \mathrm{C}$, 1-phenyl-pyrrolidin-2-one was reduced with $\mathrm{LiH}_{3} \mathrm{BNMe}_{2}$ to give 2 (36\% by GC) and 10 (64\% by GC) in $95 \%$ yield (Table 3, Entry 3). The reduction of 1-phenylpyrrolidin-2-one with $\mathrm{LiH}_{3} \mathrm{BN}(i-\mathrm{Pr})_{2}$ at $65{ }^{\circ} \mathrm{C}$ gave a smaller, but still significant amount of amino alcohol product. Reduction of 1-phenyl-pyrrolidin-2-one with $\mathrm{LiH}_{3} \mathrm{BN}(i-\mathrm{Pr})_{2}$ gave 2 (50\% by GC) and 10 (50\% by GC) in $85 \%$ yield (Table 3, Entry 4 ).

Table 3. Reduction of 1-Phenyl-pyrrolidin-2-one with LAB Reagents THF
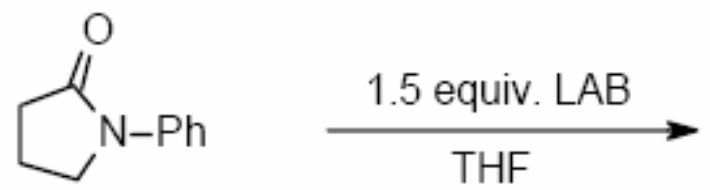

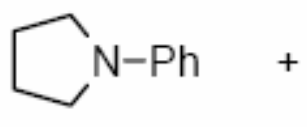

(2)

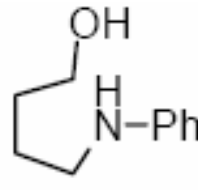

(10)

\begin{tabular}{cccccc}
\hline Entry & Reagent & Temp $\left({ }^{\circ} \mathrm{C}\right)$ & ${\text { Compound } \mathbf{2}^{\mathrm{a}}}$ & ${\text { Compound } \mathbf{1 0}^{\mathrm{a}}}^{\mathrm{a}}$ & Yield $^{\mathrm{b}}$ \\
\hline 1 & $\mathrm{LiH}_{3} \mathrm{BNMe}$ & 25 & 68 & 32 & 85 \\
2 & $\mathrm{LiH}_{3} \mathrm{BN}(i-\mathrm{Pr})_{2}$ & 25 & 60 & 40 & 95 \\
3 & $\mathrm{LiH}_{3} \mathrm{BNMe}$ & 65 & 36 & 64 & 95 \\
4 & $\mathrm{LiH}_{3} \mathrm{BN}(i-\mathrm{Pr})_{2}$ & 65 & 50 & 50 & 85 \\
\hline
\end{tabular}

${ }^{\mathrm{a}}$ Product ratios determined by capillary GC. ${ }^{\mathrm{b}}$ Isolated yields.

\section{Complementary reductions with 9-BBN and $\mathrm{LAB}$ reagents}

The complementary nature of $9-\mathrm{BBN}$ and LAB reagents was demonstrated in the reduction of a difunctional molecule that contains both an ester group and a lactam group, 1-benzyl-5-oxopyrrolidine-3-carboxylic acid methyl ester. The lactam group in this molecule was chemoselectively reduced using 2.5 molar equivalents of 9-BBN. FTIR analysis of the reaction product revealed that the ester group was left intact after the reduction. The amino ester product, 1-benzyl-pyrrolidine-3-carboxylic acid methyl ester (11), was isolated from the reaction mixture in $86 \%$ isolated yield (Scheme 1, top right). Since $9-\mathrm{BBN}$ is a mild Lewis acid that does not coordinate to the amine product, only a 2.5 equivalents of $9-\mathrm{BBN}$ was required for complete reduction of the lactam functional group. A similar reduction can be carried out using $\mathrm{BH}_{3}-\mathrm{THF}$ as the reducing agent, but only a moderate yield of the amine product was obtained when a stoichiometric amount of $\mathrm{BH}_{3}$-THF was utilized for reduction. ${ }^{8 b, c}$

The reduction of 1-benzyl-5-oxo-pyrrolidine-3-carboxylic acid methyl ester with $\mathrm{LiH}_{3} \mathrm{BNMe}_{2}$ was dependent upon both the reagent stoichiometry and the reaction temperature. The reduction of esters with $\mathrm{LAB}$ reagents is quite facile even at room temperature or at reduced temperatures. ${ }^{10 \mathrm{~b}}$ In contrast, the reduction of lactams with $\mathrm{LAB}$ reagents required elevated temperature $\left(65^{\circ} \mathrm{C}\right)$ or extended periods $(8 \mathrm{~h})$ at room temperature. Due to the difference in 
reactivity of these functional groups, we were able to selectively reduce an ester group with $\mathrm{LiH}_{3} \mathrm{BNMe}_{2}$ in the presence of a lactam group. At $-10{ }^{\circ} \mathrm{C}$, the ester in this substrate was chemoselectively reduced by stirring with 1.1 molar equivalents of $\mathrm{LiH}_{3} \mathrm{BNMe}_{2}$. The alcohol product, 1-benzyl-4-hydroxymethyl-pyrrolidin-2-one (12), was obtained in $96 \%$ isolated yield. FTIR analysis of the reaction product indicated that the lactam group remained intact after reduction (Scheme 1, bottom center). A similar reaction can be carried out with $\mathrm{LAH}_{-} \mathrm{SiO}_{2}$, which selectively reduces an ester in the presence of a lactam. ${ }^{12}$

At elevated temperature $\left(65^{\circ} \mathrm{C}\right)$ and using excess of reagent, LAB reagents act as powerful reagents and are able to reduce both lactam and ester groups. When 1-benzyl-5-oxo-pyrrolidine3-carboxylic acid methyl ester was refluxed in THF $\left(65^{\circ} \mathrm{C}\right)$ with 2.5 equivalents of $\mathrm{LiH}_{3} \mathrm{BNMe}_{2}$, both the ester and the lactam groups were completely reduced within $2 \mathrm{~h}$ as determined by FTIR analysis of a reaction aliquot. The amino alcohol product, (1-benzyl-pyrrolidin-3-yl)-methanol (13), was obtained in $88 \%$ isolated yield (Scheme 1, top left).

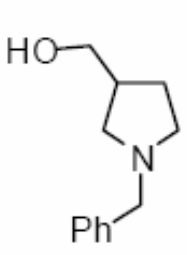

(13)

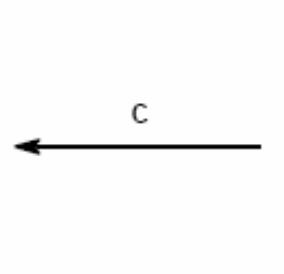

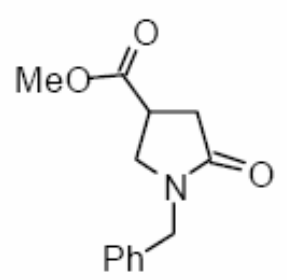

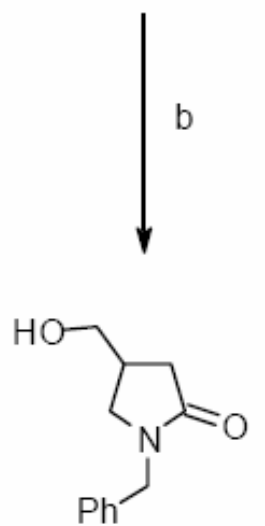

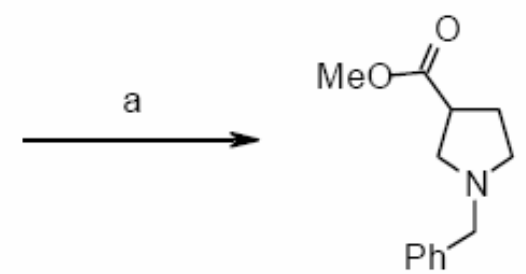

(11)

(12)
a) 2.5 equiv. 9-BBN, THF, $65^{\circ} \mathrm{C}, 1 \mathrm{~h}$ b) 1.1 equiv. $\mathrm{LiH}_{3} \mathrm{BNMe}_{2}, \mathrm{THF},-10^{\circ} \mathrm{C}, 2 \mathrm{~h}$
c) 2.5 equiv. $\mathrm{LiH}_{3} \mathrm{BNMe}_{2}, \mathrm{THF}, 65^{\circ} \mathrm{C}, 2 \mathrm{~h}$

Scheme 1. Complementary reductions with 9-BBN and LAB reagents.

A similar transformation can be carried out with the powerful $\mathrm{LiAlH}_{4}$, which reduces both lactam and ester groups. ${ }^{7 b}$ However, reductions using the non-pyrophoric LAB reagents holds a significant advantage over reductions using the pyrophoric $\mathrm{LiAlH}_{4}$. 


\section{Conclusions}

Two new methods for the reduction of $N$-alkyl lactams to the corresponding cyclic amine products using 9-BBN and $\mathrm{LAB}$ reagents have been developed. Reductions with these reagents are complementary in nature. Since $9-\mathrm{BBN}$ is a chemoselective reducing agent, the reduction of a lactam in the presence of an ester is possible. At lowered temperature $\left(10^{\circ} \mathrm{C}\right), \mathrm{LAB}$ reagents can selectively reduce an ester in the presence of lactam. At elevated temperature $\left(65^{\circ} \mathrm{C}\right), \mathrm{LAB}$ reagents act as powerful reducing agents, and reduce both lactam and ester functional groups.

In addition to being selective reducing agents, 9-BBN and LAB have many attractive qualities that make these reagents useful for the reduction of lactams. A large excess of either 9$\mathrm{BBN}$ or LAB reagents is not necessary for complete substrate reduction. Both reagents are easy to handle in the laboratory. 9-Borabicyclo[3.3.1]nonane is a nonvolatile solid that can be quickly weighed out in air. Lithium aminoborohydrides are non-pyrophoric reagents that can be easily handled in air. In contrast to $\mathrm{LiAlH}_{4}, \mathrm{LAB}$ reagents do not form strong emulsions during the aqueous work-up. Finally, reduction of lactams with 9-BBN and LAB reagents employ simple work-ups and give the cyclic amine products in good to excellent isolated yields.

\section{Experimental Section}

General Procedures. All substrates were obtained from commercial sources. All operations were carried out under a nitrogen atmosphere. All glassware, syringes and needles were oven dried and cooled to room temperature before use. Tetrahydrofuran was freshly distilled from sodium and benzophenone. Anhydrous diethyl ether was purchased and used directly. ${ }^{11} \mathrm{~B}-\mathrm{NMR}$ spectra were obtained on a Bruker ACF Multiprobe $250 \mathrm{MHz}$ NMR. Chemical shifts are reported relative to BF3-Et2O in $\delta$ ppm with upfield peaks assigned as negative. ${ }^{1} \mathrm{H}-\mathrm{NMR}$ and ${ }^{13} \mathrm{C}$-NMR spectra were obtained on a Varian Unity Plus Multiprobe $500 \mathrm{MHz}$. Chemical shifts are reported relative to TMS in $\delta \mathrm{ppm}$. Mass spectra were obtained on an Applied BioSystems Mariner Mass Spectrometer. Atomic mass units are reported as a mass to charge ratio $(\mathrm{m} / \mathrm{z})$. IR spectra were obtained on a Perkin-Elmer 1600 Series FTIR spectrometer. Units are reported as wavenumbers $(v)$ in $\mathrm{cm}^{-1}$. Reaction products were analyzed on a HP 5890 Series II gas chromatograph attached to a HP 3392A integrator. Products were separated using a $50 \mathrm{~m}$ methylsiloxane capillary column with helium as a carrier gas.

1-Benzylpyrrolidine (1). Representative procedure for reduction of 1-benzyl-pyrrolidin-2-one with 9 -BBN at $65{ }^{\circ} \mathrm{C}(10 \mathrm{mmol}$ scale $)$. A dry 250 -mL RB flask with sidearm fitted with a watercooled reflux condenser, magnetic stir bar and rubber septum was flushed with nitrogen gas. The flask was charged with 9-BBN (2.68 g, $22 \mathrm{mmol})$, anhydrous THF (44 mL) and 1-benzylpyrrolidin-2-one $(1.75 \mathrm{~g}, 10 \mathrm{mmol})$. The reaction mixture was heated to reflux $\left(65^{\circ} \mathrm{C}\right)$. After stirring at $65^{\circ} \mathrm{C}$ for $1 \mathrm{~h}$, an aliquot was taken and analyzed by ${ }^{11} \mathrm{~B}-\mathrm{NMR}$ spectroscopy. ${ }^{11} \mathrm{~B}-\mathrm{NMR}$ 
analysis $(80.25 \mathrm{MHz}, \mathrm{THF})$ showed a single peak at $\delta=+57 \mathrm{ppm}$ corresponding to the borinate anhydride of 9-BBN. At $1 \mathrm{~h}$, the reaction mixture was cooled under nitrogen gas. At $25{ }^{\circ} \mathrm{C}$, ethanolamine $(1.36 \mathrm{~g}, 1.34 \mathrm{~mL}, 22 \mathrm{mmol})$ was added via syringe. The solvent was removed under vacuum $\left(60{ }^{\circ} \mathrm{C}, 60\right.$ Torr $)$ to give an off-white solid. Pentane $(100 \mathrm{~mL})$ was added to the solid. The resulting suspension was triturated at $25^{\circ} \mathrm{C}$ for $1 \mathrm{~h}$, and then stored at $0{ }^{\circ} \mathrm{C}$ for $12 \mathrm{~h}$. The suspension was filtered in air thorough a short plug of Celite. The filter cake was rinsed with $2 \times 25 \mathrm{~mL}$ portions of ice cold pentane. The solvent was removed under vacuum $\left(35^{\circ} \mathrm{C}, 30\right.$ Torr), and then $\left(25{ }^{\circ} \mathrm{C}, 1\right.$ Torr) to give $1.55 \mathrm{~g}$ (96\% yield) of 1 as a light yellow oil. ${ }^{1} \mathrm{H}-\mathrm{NMR}$ $\left(500 \mathrm{MHz}, \mathrm{CDCl}_{3}\right) \delta=1.80-1.83$ (quint, $4 \mathrm{H}, \mathrm{J}=3 \mathrm{~Hz}$ ), 2.52-2.54 (m, 4H), $3.64(\mathrm{~s}, 2 \mathrm{H})$, 7.26-7.28 $(\mathrm{t}, 1 \mathrm{H}, \mathrm{J}=3 \mathrm{~Hz}, \mathrm{~J}=5 \mathrm{~Hz}), 7.31-7.36$ (m, 3H). ${ }^{13} \mathrm{C}-\mathrm{NMR}(125 \mathrm{MHz}, \mathrm{CDCl} 3) \delta=23.57,54.29$, 126.96, 128.31, 129.03, 139.55. HRMS for $\mathrm{C}_{11} \mathrm{H}_{15} \mathrm{~N}_{1}\left(\mathrm{M}^{+}+\mathrm{H}\right)$ calcd: 162.1277; found : 162.1259 .

1-Phenyl-pyrrolidine (2). Reduction of 1-phenyl-pyrrolidin-2-one with 9-BBN at $65{ }^{\circ} \mathrm{C}$ (10 mmol). Light yellow oil, $1.46 \mathrm{~g}$ ( 99\% yield). bp =83-85 ${ }^{\circ} \mathrm{C} @ 0.3$ Torr. ${ }^{1} \mathrm{H}$ NMR (500 $\left.\mathrm{MHz} \mathrm{CDCl}_{3}\right) \delta=2.04-2.07$ (quint, $4 \mathrm{H}, \mathrm{J}=4 \mathrm{~Hz}$ ), 3.33-3.35 (m, 4H), 6.63-6.64 (d, 2H, J = $8 \mathrm{~Hz}$ ), 6.71-6.74 (t, $1 \mathrm{H}, \mathrm{J}=7 \mathrm{~Hz}), 7.27-7.32(\mathrm{~m}, 2 \mathrm{H}, \mathrm{J}=2 \mathrm{~Hz}, \mathrm{~J}=7 \mathrm{~Hz}) .{ }^{13} \mathrm{C} \mathrm{NMR}\left(125 \mathrm{MHz}, \mathrm{CDCl}_{3}\right)$ $\delta=25.59,47.70,111.78,115.50,129.25,148.11$. HRMS for $\mathrm{C}_{10} \mathrm{H}_{13} \mathrm{~N}_{1}\left(\mathrm{M}^{+}+\mathrm{H}\right)$ calcd: 148.1121; found: 148.1084 .

1-Cyclohexyl-pyrrolidine (3). Reduction of 1-cyclohexyl-pyrrolidin-2-one with 9BBN at $65{ }^{\circ} \mathrm{C}$ (10 mmol scale). Light yellow oil, $1.26 \mathrm{~g}$ (82\% yield). ${ }^{1} \mathrm{H}-\mathrm{NMR}\left(500 \mathrm{MHz}, \mathrm{CDCl}_{3}\right)$ $\delta=1.15-1.29(\mathrm{~m}, 5 \mathrm{H}), 1.55-1.64(\mathrm{~m}, 2 \mathrm{H}), 1.75-1.81(\mathrm{~m}, 6 \mathrm{H}), 1.94-1.99(\mathrm{~m}, 3 \mathrm{H}), 2.55-2.60(\mathrm{~m}$, $4 \mathrm{H}) .{ }^{13} \mathrm{C} \mathrm{NMR}\left(125 \mathrm{MHz}, \mathrm{CDCl}_{3}\right) \delta=23.28,25.28,26.19,32.31,51.58,63.87$. HRMS for $\mathrm{C}_{10} \mathrm{H}_{19} \mathrm{~N}_{1}\left(\mathrm{M}^{+}+\mathrm{H}\right)$ calcd: 154.1590 ; found: 154.1565 .

1-Octyl-pyrrolidine (4). Reduction of 1-octyl-pyrrolidin-2-one with 9-BBN at $65{ }^{\circ} \mathrm{C}$ (10 mmol scale). Light yellow oil, 1.71 g (93\% yield). bp =93-95 ${ }^{\circ} \mathrm{C} @ 0.6$ Torr. ${ }^{1} \mathrm{HNMR}(500$ $\left.\mathrm{MHz}, \mathrm{CDCl}_{3}\right) \delta=0.84-0.87(\mathrm{~m}, 3 \mathrm{H}, \mathrm{J}=7 \mathrm{~Hz}), 1.25-1.28(\mathrm{~m}, 10 \mathrm{H}), 1.48-1.50$ (quint, $2 \mathrm{H}, \mathrm{J}=7$ $\mathrm{Hz}), 1.74-1.77(\mathrm{~m}, 4 \mathrm{H}), 2.37-2.41(\mathrm{dt}, 2 \mathrm{H}, \mathrm{J}=2 \mathrm{~Hz}, \mathrm{~J}=8 \mathrm{~Hz}), 2.45-2.49(\mathrm{~m}, 4 \mathrm{H}) .{ }^{13} \mathrm{C}$ NMR $(125$ $\left.\mathrm{MHz} \mathrm{CDCl}_{3}\right) \delta=14.16,22.75,23.48,27.85,29.22,29.34,29.67,31.94,54.34$, 56.84. HRMS for $\mathrm{C}_{12} \mathrm{H}_{25} \mathrm{~N}_{1}\left(\mathrm{M}^{+}+\mathrm{H}\right)$ calcd: $184.2060 ; 184.2085$ found.

1-Dodecyl-pyrrolidine (5). Reduction of 1-dodecylpyrrolidin-2-one with 9-BBN at $65{ }^{\circ} \mathrm{C}$ (10 mmol scale). Light yellow oil, $2.33 \mathrm{~g}$ (97\% yield). ${ }^{1} \mathrm{H}-\mathrm{NMR}\left(500 \mathrm{MHz}, \mathrm{CDCl}_{3}\right) \delta=0.86$ 0.89 (t, 3H, J = 8 Hz), 1.26-1.29 (m, 20H), 1.48-1.51 (quint, $2 \mathrm{H}, \mathrm{J}=7 \mathrm{~Hz}$ ), 1.76-1.78 (m, 4H), 2.39-2.42 (t, 3H, J = 8 Hz), 2.47-2.49 (m, 4H). ${ }^{13} \mathrm{C}-\mathrm{NMR}\left(125 \mathrm{MHz}, \mathrm{CDCl}_{3}\right) \delta=14.19,22.78$, 23.49, 27.88, 29.23, 29.45, 29.71, 32.02, 54.35, 56.87. HRMS for $\mathrm{C}_{16} \mathrm{H}_{33} \mathrm{~N}_{1}\left(\mathrm{M}^{+}+\mathrm{H}\right)$ calcd: 240.2786; found: 240.2786 .

(+)-3-Methyl-2-(2-methyl-pyrrolidin-1-yl)-butan-1-ol (6). Reduction of (3S-cis)-(+)-3isopropyl-7a-methyl-tetrahydro-pyrrolo[2,1-b]oxazol-5-one with 3.2 equivalents of 9-BBN at $65{ }^{\circ} \mathrm{C}$ ( $5 \mathrm{mmol}$ scale). Purification of the crude reaction product by column chromatography (30 \% EtOAc/Hex) gave (+)-3-methyl-2-(2-methyl-pyrrolidin-1-yl)-butan-1-ol (6) (0.803 g, 54\% yield) as a light yellow oil. ${ }^{1} \mathrm{H}-\mathrm{NMR}\left(500 \mathrm{MHz}, \mathrm{CDCl}_{3}\right) \delta=0.82-0.83(\mathrm{~d}, 3 \mathrm{H}, \mathrm{J}=7 \mathrm{~Hz}), 0.93-0.95$ 
$(\mathrm{d}, 3 \mathrm{H}, \mathrm{J}=7 \mathrm{~Hz}), 1.01-1.02(\mathrm{~d}, 3 \mathrm{H}, \mathrm{J}=8 \mathrm{~Hz}), 1.33-1.39(\mathrm{~m}, 1 \mathrm{H}), 1.68-1.74(\mathrm{~m}, 2 \mathrm{H}), 1.79-1.94$ (dm, 2H), 2.51-2.57 (m, 1H), 2.60-2.65 (q, 1H, J = 8 Hz), 2.77-2.80 (m, 1H), 3.05-3.12 (m, 2H), 3.50-3.54 (q, $\mathrm{J}=6 \mathrm{~Hz}) .{ }^{13} \mathrm{CNMR}\left(125 \mathrm{MHz}, \mathrm{CDCl}_{3}\right) \delta=23.28,25.28,26.19,32.31,51.58,63.87$. HRMS for $\mathrm{C}_{10} \mathrm{H}_{21} \mathrm{~N}_{1} \mathrm{O}_{1}\left(\mathrm{M}^{+}+\mathrm{H}\right)$ calcd: 172.1696; found: 172.1695 . $[\alpha]_{\mathrm{D}}{ }^{26}=+51.1(\mathrm{c}=0.03$, $\left.\mathrm{CHCl}_{3}\right)$.

Indole (7). Reduction of oxindole with 1.2 equivalents of 9-BBN at $65{ }^{\circ} \mathrm{C}$ (10 mmol scale). Off-white solid, $0.968 \mathrm{~g}(83 \%$ yield $) . \mathrm{mp}=48-50{ }^{\circ} \mathrm{C} .{ }^{1} \mathrm{H}-\mathrm{NMR}\left(\mathrm{CDCl}_{3}, 500 \mathrm{MHz}\right) \delta=6.71(\mathrm{~m}$, $1 \mathrm{H}), 7.18-7.19$ (t, 1H, J = 3 Hz), 7.30-7.33 (t, 1H, J = 2 Hz, J = $8 \mathrm{~Hz}$ ), 7.36-7.39 (t, 2H, J = 8 $\mathrm{Hz}), 7.42-7.44(\mathrm{t}, 2 \mathrm{H}, \mathrm{J}=8 \mathrm{~Hz}) .{ }^{13} \mathrm{C}-\mathrm{NMR}\left(\mathrm{CDCl}_{3}, 125 \mathrm{MHz}\right) \delta=102.60,111.45,120.06,120.99$, $122.17,124.17,124.17,124.64,128.10,136.05$. FTIR $\left(\mathrm{THF}, \mathrm{cm}^{-1}\right) v=1732$ (st $\mathrm{C}=\mathrm{O}$ lactam). HRMS for $\mathrm{C}_{8} \mathrm{H}_{7} \mathrm{O}_{1}\left(\mathrm{M}^{+}+\mathrm{H}\right)$ calcd: 118.1502; found 118.1504.

1-Methyl-1,2,3,4-tetrahydro-quinoline (8). Reduction of 1-methyl-3,4-dihydro-1H-quinolin2-one with 9-BBN at $65{ }^{\circ} \mathbf{C}\left(5 \mathrm{mmol}\right.$ scale). Light yellow oil, $0.706 \mathrm{~g}$ (96 \% yield). ${ }^{1} \mathrm{H}-\mathrm{NMR}$ $\left(500 \mathrm{MHz}, \mathrm{CDCl}_{3}\right) \delta=2.00-2.05(\mathrm{~m}, 2 \mathrm{H}, \mathrm{J}=2 \mathrm{~Hz}, \mathrm{~J}=7 \mathrm{~Hz}), 2.80-2.82(\mathrm{t}, 2 \mathrm{H}, \mathrm{J}=7 \mathrm{~Hz}), 2.93(\mathrm{~s}$, $3 \mathrm{H}), 3.24-3.27$ (t, 2H, J = 6 Hz), 6.63-6.66 (t, 2H, J = 1 Hz, J = $8 \mathrm{~Hz}), 6.98-7.00$ (dm, 1H, J = 1 $\mathrm{Hz}, \mathrm{J}=7 \mathrm{~Hz}), 7.10-7.13(\mathrm{tm}, 1 \mathrm{H}, \mathrm{J}=1 \mathrm{~Hz}, \mathrm{~J}=8 \mathrm{~Hz}) .{ }^{13} \mathrm{C}-\mathrm{NMR}\left(125 \mathrm{MHz}, \mathrm{CDCl}_{3}\right) \delta=22.59$, 27.93, 39.27, 51.41, 111.11, 116.35, 123.02, 127.18, 128.93, 146.87. HRMS for $\mathrm{C}_{10} \mathrm{H}_{13} \mathrm{~N}_{1}\left(\mathrm{M}^{+}+\right.$ H) calcd: 148.1121 ; found: 148.1121 .

4-Methyl-3, 4-dihydro-2H-benzomorpholine (9). Reduction of 4-methyl-2H-1, 4benzoxazin-3(4H)-one with 9-BBN at $65{ }^{\circ} \mathrm{C}(5 \mathrm{mmol}$ scale). Dark yellow oil, $0.502 \mathrm{~g}$ (75\% yield). ${ }^{1} \mathrm{H}$ NMR $\left(500 \mathrm{MHz}, \mathrm{CDCl}_{3}\right) \delta=2.90(\mathrm{~s}, 3 \mathrm{H}), 3.27-3.29(\mathrm{t}, 2 \mathrm{H}, \mathrm{J}=5 \mathrm{~Hz}), 4.32-4.33(\mathrm{t}, 3 \mathrm{H}$, $\mathrm{J}=4 \mathrm{~Hz}), 6.66-6.71(\mathrm{~m}, 2 \mathrm{H}, \mathrm{J}=2 \mathrm{~Hz}, \mathrm{~J}=8 \mathrm{~Hz}), 6.79-6.88(\mathrm{dd}, 1 \mathrm{H}, \mathrm{J}=2 \mathrm{~Hz}, \mathrm{~J}=8 \mathrm{~Hz}), 6.85-$ $6.88(\mathrm{td}, 1 \mathrm{H}, \mathrm{J}=2 \mathrm{~Hz}, \mathrm{~J}=8 \mathrm{~Hz}) .{ }^{13} \mathrm{C} \mathrm{NMR}\left(125 \mathrm{MHz}, \mathrm{CDCl}_{3}\right) \delta=38.92,49.34,64.99,112.68$, 116.03, 118.35, 121.53, 136.71, 144.43. HRMS for $\mathrm{C}_{9} \mathrm{H}_{11} \mathrm{~N}_{1} \mathrm{O}_{1}\left(\mathrm{M}^{+}+\mathrm{H}\right)$ calcd: 150.0913; found $: 150.0875$.

1-Benzyl-pyrrolidine-3-carboxylic acid methyl ester (11). Reduction of 1-benzyl-5-oxopyrrolidine-3-carboxylic acid methyl ester with 2.5 equivalents of $9-\mathrm{BBN}$ at $65{ }^{\circ} \mathrm{C}(10 \mathrm{mmol}$ scale). Clear viscous, light yellow oil, $1.88 \mathrm{~g}$ (86\% yield). ${ }^{1} \mathrm{H}-\mathrm{NMR}\left(500 \mathrm{MHz}, \mathrm{CDCl}_{3}\right) \delta=$ 2.10-2.14 (m, 2H), 2.52-2.55 (quartet, $1 \mathrm{H}, \mathrm{J}=9 \mathrm{~Hz}$ ), 2.63-2.66 (dd, $1 \mathrm{H}, \mathrm{J}=2 \mathrm{~Hz}, \mathrm{~J}=8 \mathrm{~Hz}$ ), 2.72-2.74 (m, 1H, J = $3 \mathrm{~Hz}$ ) 2.91-2.92 (t, 1H, J = 9 Hz), 3.04-3.06 (quintet, 1H, J = $9 \mathrm{~Hz}$ ), 3.64 $(\mathrm{s}, 2 \mathrm{H}), 3.69(\mathrm{~s}, 3 \mathrm{H}), 7.26-7.28(\mathrm{~m}, 2 \mathrm{H}), 7.30-7.34(\mathrm{~m}, 3 \mathrm{H}) .{ }^{13} \mathrm{C}-\mathrm{NMR}\left(125 \mathrm{MHz}, \mathrm{CDCl}_{3}\right) \delta=$ 27.77, 42.08, 51.95, 53.84, 56.78, 60.19, 127.15, 128.39, 128.90, 130.84, 175.60. FTIR $\left(\mathrm{THF}, \mathrm{cm}^{-1}\right) v=1735$ (st $\mathrm{C}=\mathrm{O}$ ester). HRMS for $\mathrm{C}_{13} \mathrm{H}_{17} \mathrm{~N}_{1} \mathrm{O}_{2}\left(\mathrm{M}^{+}+\mathrm{H}\right)$ calcd: 220.1332 ; found: 220.1365 .

Representative procedure for synthesis of lithium dimethylaminoborohydride (1 M solution in THF)

A dry $125-\mathrm{mL}$ serum vial fitted with a rubber septum and equipped with a magnetic stir bar was charged with dimethylamine-borane $(5.89 \mathrm{~g}, 100 \mathrm{mmol})$ and anhydrous THF $(60 \mathrm{~mL})$. At $0{ }^{\circ} \mathrm{C}$, $n$-butyllithium in hexanes $(40 \mathrm{~mL}, 2.5 \mathrm{M}, 100 \mathrm{mmol})$ was added dropwise via syringe. After 
stirring at $0{ }^{\circ} \mathrm{C}$ for $1 \mathrm{~h}$, an aliquot was taken and analyzed by ${ }^{~ " B-N M R ~ s p e c t r o s c o p y . ~}{ }^{11} \mathrm{~B}-\mathrm{NMR}$ analysis $(80.25 \mathrm{MHz}$, THF) showed the solution to be lithium dimethylaminoborohydride $\delta=$ $15.5 \mathrm{ppm}(\mathrm{q}, \mathrm{J}=85 \mathrm{~Hz})$.

\section{Representative procedure for synthesis of lithium diisopropylaminoborohydride (1 M solution in THF)}

A dry 125-mL serum vial equipped with a magnetic stir bar and fitted with a rubber septum was charged with diisopropylamine $(10.12 \mathrm{~g}, 14.02 \mathrm{~mL}, 100 \mathrm{mmol})$ and anhydrous THF (36 mL). At $0{ }^{\circ} \mathrm{C}$, borane-dimethylsulfide $(10 \mathrm{~mL}, 10 \mathrm{M}, 100 \mathrm{mmol})$ was added dropwise via syringe. After stirring at $0{ }^{\circ} \mathrm{C}$ for $1 \mathrm{~h}$, an aliquot was taken and analyzed by ${ }^{11} \mathrm{~B}-\mathrm{NMR}$ spectroscopy. ${ }^{11} \mathrm{~B}-\mathrm{NMR}$ analysis $(80.25 \mathrm{MHz}$, THF) showed the solution to be diisopropylamine-borane $\delta=-19.9$ (q, $\mathrm{J}=$ $88 \mathrm{~Hz}$ ). At $0{ }^{\circ} \mathrm{C}$, added $n$-butyllithium in hexanes $(40 \mathrm{~mL}, 2.5 \mathrm{M}, 100 \mathrm{mmol}$ ) was added dropwise via cannula. After stirring at $0{ }^{\circ} \mathrm{C}$ for $1 \mathrm{~h}$, an aliquot was taken and analyzed by ${ }^{11} \mathrm{~B}-$ NMR spectroscopy. ${ }^{11} \mathrm{~B}-\mathrm{NMR}$ analysis $(80.25 \mathrm{MHz}, \mathrm{THF})$ indicated the solution to be lithium diisopropylaminoborohydride $\delta=-25.2 \mathrm{ppm}(\mathrm{q}, \mathrm{J}=84 \mathrm{~Hz}$ ).

1-Benzylpyrrolidine (1). Reduction of 1-benzyl-pyrrolidin-2-one with lithium dimethylaminoborohydride at $65^{\circ} \mathrm{C}(10 \mathrm{mmol}$ scale $)$ : A dry 100-mL RB flask with sidearm was fitted with a water-cooled reflux condenser, magnetic stir bar and rubber septum was flushed with nitrogen gas. At $0{ }^{\circ} \mathrm{C}$, the flask was charged with lithium dimethylaminoborohydride (15 $\mathrm{mL}, 1 \mathrm{M}, 15 \mathrm{mmol})$ and 1-benzyl-pyrrolidin-2-one $(1.75 \mathrm{~g}, 10 \mathrm{mmol})$ via syringe. The reaction mixture was heated to reflux $\left(65^{\circ} \mathrm{C}\right)$ for $2 \mathrm{~h}$. After stirring at $65^{\circ} \mathrm{C}$ for $2 \mathrm{~h}$, an aliquot was taken and analyzed by FTIR spectroscopy. FTIR analysis (THF, $\mathrm{cm}^{-1}$ ) showed the disappearance of the lactam carbonyl peak at $v=1659 \mathrm{~cm}^{-1}$. After $2 \mathrm{~h}$, the reaction mixture was cooled under nitrogen gas to $0{ }^{\circ} \mathrm{C}$ and the reaction was quenched with $25 \mathrm{~mL}$ of $3 \mathrm{M} \mathrm{HCl}$ (Caution: Hydrogen evolution!). The aqueous layer was extracted with $4 \times 20 \mathrm{~mL}$ portions of EE. At $0{ }^{\circ} \mathrm{C}$, solid $\mathrm{NaOH}$ was added to aqueous layer until strongly basic $(\mathrm{pH}=12)$ to litmus. The aqueous layer was extracted with $4 \times 20 \mathrm{~mL}$ portions of $\mathrm{THF} / \mathrm{Et}_{2} \mathrm{O}$. The organic layers were combined, dried over anhydrous $\mathrm{MgSO} 4$, and filtered. The solvent was removed under vacuum $\left(35^{\circ} \mathrm{C}, 30\right.$ Torr $)$, and then $\left(25{ }^{\circ} \mathrm{C}, 1\right.$ Torr) to give $1.39 \mathrm{~g}$ (86\% yield) of 1 as a light yellow oil. ${ }^{1} \mathrm{H}-\mathrm{NMR}$ (500 $\left.\mathrm{MHz}, \mathrm{CDCl}_{3}\right) \delta=1.80-1.82$ (quint, $4 \mathrm{H}, \mathrm{J}=3 \mathrm{~Hz}$ ), 2.52-2.56 (m, 4H), $3.63(\mathrm{~s}, 2 \mathrm{H}), 7.24-7.28(\mathrm{t}$, $2 \mathrm{H}, \mathrm{J}=7 \mathrm{~Hz}), 7.32-7.37(\mathrm{~m}, 4 \mathrm{H}, \mathrm{J}=3 \mathrm{~Hz}, \mathrm{~J}=8 \mathrm{~Hz}) .{ }^{13} \mathrm{C}-\mathrm{NMR}\left(125 \mathrm{MHz}, \mathrm{CDCl}_{3}\right) \delta=23.57$, 54.28, 60.85, 126.99, 128.33, 129.04, 139.42. HRMS for $\mathrm{C}_{11} \mathrm{H}_{15} \mathrm{~N}_{1}\left(\mathrm{M}^{+}+\mathrm{H}\right)$ calcd: 162.1277; found: 162.1259 .

1-Benzylpyrrolidine (1). Reduction of 1-benzyl-pyrrolidin-2-one with lithium diisopropylaminoborohydride at $65^{\circ} \mathbf{C}(10 \mathrm{mmol}$ scale). Light yellow oil, $1.39 \mathrm{~g}$ (86 \% yield). ${ }^{1} \mathrm{H}-\mathrm{NMR}\left(500 \mathrm{MHz}, \mathrm{CDCl}_{3}\right) \delta=1.80-1.82$ (quint, 4H, J = $3 \mathrm{~Hz}$ ), 2.52-2.56 (m, 4H), 3.63(s, 2H), 7.24-7.28 (t, 2H, J = $7 \mathrm{~Hz}), 7.32-7.37$ (m, 4H, J = $3 \mathrm{~Hz}, \mathrm{~J}=8 \mathrm{~Hz}) .{ }^{13} \mathrm{C}-\mathrm{NMR}\left(125 \mathrm{MHz}, \mathrm{CDCl}_{3}\right)$ $\delta=23.57,54.28,60.85,126.99,128.33,129.04,139.42$. HRMS for $\mathrm{C}_{11} \mathrm{H}_{15} \mathrm{~N}_{1}\left(\mathrm{M}^{+}+\mathrm{H}\right)$ calcd: 162.1277; found: 162.1259 .

1-Cyclohexyl-pyrrolidine (3). Reduction of 1-cyclohexylpyrrolidin-2-one with lithium 
dimethylaminoborohydride at $65{ }^{\circ} \mathbf{C}$ (10 mmol scale). Light yellow oil, $1.22 \mathrm{~g}$ (80\% yield). ${ }^{1} \mathrm{H}-\mathrm{NMR}\left(500 \mathrm{MHz}, \mathrm{CDCl}_{3}\right) \delta=1.15-1.26(\mathrm{~m}, 4 \mathrm{H}), 1.58-1.61(\mathrm{~m}, 1 \mathrm{H}), 1.72-1.78(\mathrm{~m}, 6 \mathrm{H}), 1.91-$ $1.96(\mathrm{~m}, 4 \mathrm{H}), 2.54-2.57(\mathrm{~m}, 4 \mathrm{H}) .{ }^{13} \mathrm{C}-\mathrm{NMR}\left(125 \mathrm{MHz}, \mathrm{CDCl}_{3}\right) \delta=23.32,25.33,26.22,32.35$, 51.63, 63.92. HRMS for $\mathrm{C}_{10} \mathrm{H}_{19} \mathrm{~N}_{1}\left(\mathrm{M}^{+}+\mathrm{H}\right)$ calcd: 154.1590 ; found: 154.1565 .

1-Octyl-pyrrolidine (4). Reduction of 1-octyl-pyrrolidin-2-one with lithium dimethylaminoborohydride at $65^{\circ} \mathbf{C}(\mathbf{1 0} \mathbf{~ m m o l ~ s c a l e ) . ~ C l e a r , ~ c o l o r l e s s ~ o i l , ~} 1.62 \mathrm{~g}$ (89 \% yield). ${ }^{1} \mathrm{H}-\mathrm{NMR}\left(500 \mathrm{MHz}, \mathrm{CDCl}_{3}\right) \delta=0.85-0.88(\mathrm{t}, 3 \mathrm{H}, \mathrm{J}=8 \mathrm{~Hz}$ ), 1.26-1.29 (t, 10H), 1.48-1.51 (quint, $2 \mathrm{H}, \mathrm{J}=7 \mathrm{~Hz}$ ), 1.75-1.77 (quint, 4H, J = $4 \mathrm{~Hz}$ ), 2.37-2.41 (dt, 2H, J = 2 Hz, J = $8 \mathrm{~Hz}$ ), 2.45-2.48 $(\mathrm{m}, 4 \mathrm{H}) .{ }^{13} \mathrm{C}-\mathrm{NMR}\left(125 \mathrm{MHz}, \mathrm{CDCl}_{3}\right) \delta=14.18,22.75,23.49,27.89,29.26,29.36,29.68,31.95$, 54.37, 56.87. HRMS for $\mathrm{C}_{12} \mathrm{H}_{25} \mathrm{~N}_{1}\left(\mathrm{M}^{+}+\mathrm{H}\right)$ calcd: 184.2060; found: 184.2085.

1-Dodecyl-pyrrolidine (5). Reduction of 1-dodecyl-pyrrolidin-2-one with lithium dimethylaminoborohydride at $65{ }^{\circ} \mathbf{C}(10 \mathrm{mmol}$ scale). Clear, light yellow oil, $2.29 \mathrm{~g}$ (96\% yield). ${ }^{1} \mathrm{H}-\mathrm{NMR}\left(500 \mathrm{MHz}, \mathrm{CDCl}_{3}\right) \delta=0.85-0.88$ (t, 3H, J = $\left.3 \mathrm{~Hz}\right), 1.25-1.30$ (br m, 18H), 1.481.51 (quint, $2 \mathrm{H}, \mathrm{J}=8 \mathrm{~Hz}$ ), 1.74-1.77 (quint, $4 \mathrm{H}, \mathrm{J}=3 \mathrm{~Hz}$ ), 2.37-2.41 (t, 2H, J = $3 \mathrm{~Hz}$ ), 2.45-2.47 $(\mathrm{m}, 4 \mathrm{H}, \mathrm{J}=2 \mathrm{~Hz}, \mathrm{~J}=3 \mathrm{~Hz}) .{ }^{13} \mathrm{C}-\mathrm{NMR}\left(125 \mathrm{MHz}, \mathrm{CDCl}_{3}\right) \delta=14.19$, 22.77, 23.48, 27.88, 29.23, 29.45, 29.73, 32.02, 54.34, 56.86; HRMS for $\mathrm{C}_{16} \mathrm{H}_{33} \mathrm{~N}_{1}\left(\mathrm{M}^{+}+\mathrm{H}\right)$ calcd: 240.2786; found: 240.2786 .

Attempted reduction of oxindole with lithium dimethylaminoborohydride at $65{ }^{\circ} \mathrm{C}$ (10 mmol scale). A dry 100-mL RB flask with sidearm fitted with a water-cooled reflux condenser, magnetic stirring bar and rubber septum was flushed with nitrogen gas. The flask was charged with a THF solution of lithium dimethylaminoborohydride (15 mL, $1 \mathrm{M}, 15 \mathrm{mmol})$. At $0{ }^{\circ} \mathrm{C}$, oxindole $(1.33 \mathrm{~g}, 10 \mathrm{mmol})$ in anhydrous THF $(10 \mathrm{~mL})$ was added (Caution: Exothermic reaction!). The reaction was heated to reflux $\left(65^{\circ} \mathrm{C}\right)$. After stirring at $65^{\circ} \mathrm{C}$ for $2 \mathrm{~h}$, an aliquot was taken and analyzed by FTIR spectroscopy. FTIR analysis (THF, $\mathrm{cm}^{-1}$ ) showed the disappearance of the lactam carbonyl peak at $v=1732 \mathrm{~cm}^{-1}$. After $2 \mathrm{~h}$, the reaction mixture was cooled under nitrogen gas to $0{ }^{\circ} \mathrm{C}$ and the reaction was quenched with $3 \mathrm{M} \mathrm{HCl}(25 \mathrm{~mL})$ (Caution: Hydrogen evolution!). The aqueous layer was extracted with 4 x $20 \mathrm{~mL}$ portions of $\mathrm{THF} / \mathrm{Et}_{2} \mathrm{O}$. The organic layers were combined, dried over $\mathrm{MgSO}_{4}$, and filtered. The solvent was removed under vacuum $\left(35^{\circ} \mathrm{C}, 30\right.$ Torr $)$, and then $\left(25^{\circ} \mathrm{C}, 1\right.$ Torr $)$ to give $1.13 \mathrm{~g}$ ( $85 \%$ recovery) of oxindole as a white solid; $\mathrm{mp}=114-116{ }^{\circ} \mathrm{C} .{ }^{1} \mathrm{H}-\mathrm{NMR}\left(\mathrm{CDCl}_{3}, 500 \mathrm{MHz}\right) \delta=3.56(\mathrm{~s}, 2 \mathrm{H})$, 6.92-6.94 (d, 1H, J = $8 \mathrm{~Hz}$ ), 7.01-7.04 (t, 1H, J = $8 \mathrm{~Hz}$ ), 7.21-7.24 (t, 2H, J = $8 \mathrm{~Hz}$ ), 9.08 (br s, 1H). ${ }^{13} \mathrm{CNMR}\left(\mathrm{CDCl}_{3}, 125 \mathrm{MHz}\right) \delta=36.45,110.24,122.43,122.66,125.42,128.03,142.79$, 178.44. FTIR (THF, $\left.\mathrm{cm}^{-1}\right) v=1732$ (st $\mathrm{C}=\mathrm{O}$ lactam). HRMS for $\mathrm{C}_{8} \mathrm{H}_{7} \mathrm{O}_{1}\left(\mathrm{M}^{+}+\mathrm{H}\right)$ calcd: 134.0600; found: 134.0926 .

1-Methyl-1, 2, 3, 4-tetrahydro-quinoline (8). Reduction of 1-methyl-3, 4-dihydro-1H-quinol2-one with lithium dimethylaminoborohydride at $65{ }^{\circ} \mathbf{C}$ (5 mmol scale). Light yellow oil, $0.706 \mathrm{~g}$ (96 \% yield). ${ }^{1} \mathrm{H}-\mathrm{NMR}\left(500 \mathrm{MHz}, \mathrm{CDCl}_{3}\right) \delta=2.00-2.05(\mathrm{~m}, 2 \mathrm{H}, \mathrm{J}=2 \mathrm{~Hz}, \mathrm{~J}=7 \mathrm{~Hz})$, 2.80-2.82 (t, 2H, J = 7 Hz), $2.93(\mathrm{~s}, 3 \mathrm{H}), 3.24-3.27$ (t, 2H, J = 6 Hz), 6.63-6.66 (t, 2H, J = $1 \mathrm{~Hz}, \mathrm{~J}$ $=8 \mathrm{~Hz}), 6.98-7.00(\mathrm{dm}, 1 \mathrm{H}, \mathrm{J}=1 \mathrm{~Hz}, \mathrm{~J}=7 \mathrm{~Hz}), 7.10-7.13(\mathrm{tm}, 1 \mathrm{H}, \mathrm{J}=1 \mathrm{~Hz}, \mathrm{~J}=8 \mathrm{~Hz})$. 
${ }^{13} \mathrm{C}-\mathrm{NMR}\left(125 \mathrm{MHz}, \mathrm{CDCl}_{3}\right) \delta=22.59,27.93,39.27,51.41,111.11,116.35,123.02,127.18$, 128.93, 146.87. HRMS for $\mathrm{C}_{10} \mathrm{H}_{13} \mathrm{~N}_{1}\left(\mathrm{M}^{+}+\mathrm{H}\right)$ calcd: 148.1121 ; found: 148.1121 .

4-Methyl-3,4-dihydro-2H-benzo[1,4]oxazine (9). Reduction of 4-methyl-4H-1, 4benzo[1,4]oxazin-3-one with lithium dimethylaminoborohydride at $65{ }^{\circ} \mathrm{C}$ (5 mmol scale). Dark yellow oil, $0.502 \mathrm{~g}$ (75 \% yield). ${ }^{1} \mathrm{H}$ NMR $\left(500 \mathrm{MHz}, \mathrm{CDCl}_{3}\right) \delta=2.90$ (s, 3H), 3.27-3.29 (t, $2 \mathrm{H}, \mathrm{J}=5 \mathrm{~Hz}), 4.32-4.33$ (t, 3H, J = $4 \mathrm{~Hz}), 6.66-6.71(\mathrm{~m}, 2 \mathrm{H}, \mathrm{J}=2 \mathrm{~Hz}, \mathrm{~J}=8 \mathrm{~Hz}), 6.79-6.88$ (dd, $1 \mathrm{H}, \mathrm{J}=2 \mathrm{~Hz}, \mathrm{~J}=8 \mathrm{~Hz}), 6.85-6.88(\mathrm{td}, 1 \mathrm{H}, \mathrm{J}=2 \mathrm{~Hz}, \mathrm{~J}=8 \mathrm{~Hz}) .{ }^{13} \mathrm{C}$ NMR $\left(125 \mathrm{MHz}, \mathrm{CDCl}_{3}\right)$ $\delta=38.92,49.34,64.99,112.68,116.03,118.35,121.53,136.71,144.43$. HRMS for $\mathrm{C}_{9} \mathrm{H}_{11} \mathrm{~N}_{1} \mathrm{O}_{1}$ $\left(\mathrm{M}^{+}+\mathrm{H}\right)$ calcd: 150.0913 ; found: 150.0875 .

Mixture of 1-phenyl-pyrrolidine (2) and 4-phenylamino-butan-1-ol (10). Reduction of 1phenylpyrrolidin-2-one with lithium dimethylaminoborohydride at $25^{\circ} \mathrm{C}$ (10 mmol scale). Clear, colorless oil as mixture of $\mathbf{2}$ and $\mathbf{1 0}$ (1.25 g, $85 \%$ yield). Analysis by capillary gas chromatography (isotherm, $\left.125{ }^{\circ} \mathrm{C}\right)$ showed $2\left(t_{R}=11.06 \mathrm{~min}, 68 \%\right)$ and $10\left(t_{R}=17.70 \mathrm{~min}\right.$, $32 \%$ ) as determined by GC standards. HRMS for $2 \mathrm{C}_{10} \mathrm{H}_{13} \mathrm{~N}_{1}\left(\mathrm{M}^{+}+\mathrm{H}\right)$ calcd: 148.1121; found: 148.1093. HRMS for $10 \mathrm{C}_{10} \mathrm{H}_{15} \mathrm{~N}_{1} \mathrm{O}_{1}\left(\mathrm{M}^{+}+\mathrm{H}\right)$ calcd: 166.1220; found: 166.1226.

Mixture of 1-phenyl-pyrrolidine (2) and 4-phenylamino-butan-1-ol (10). Reduction of 1phenylpyrrolidin-2-one with lithium diisopropylaminoborohydride at $25^{\circ} \mathrm{C} \mathrm{(5} \mathrm{mmol} \mathrm{scale).}$ Clear, colorless oil as mixture of 2 and 10 (0.702 g, 95\% yield). Analysis by capillary gas chromatography (isotherm, $\left.125{ }^{\circ} \mathrm{C}\right)$ showed $2\left(t_{R}=11.06 \mathrm{~min}, 60 \%\right)$ and $10\left(t_{R}=17.70 \mathrm{~min}\right.$, $40 \%$ ) as determined by GC standards. HRMS for $2 \mathrm{C}_{10} \mathrm{H}_{13} \mathrm{~N}_{1}\left(\mathrm{M}^{+}+\mathrm{H}\right)$ calcd: 148.1121; found: 148.1093. HRMS for $10 \mathrm{C}_{10} \mathrm{H}_{15} \mathrm{~N}_{1} \mathrm{O}_{1}\left(\mathrm{M}^{+}+\mathrm{H}\right)$ calcd: 166.1220; found: 166.1226 .

Mixture of 1-phenyl-pyrrolidine (2) and 4-phenylamino-butan-1-ol (10). Reduction of 1phenyl-2-pyrrolidinone with lithium dimethylaminoborohydride at $65{ }^{\circ} \mathrm{C}(10 \mathrm{mmol}$ scale). Clear, colorless oil as mixture of $\mathbf{2}$ and $\mathbf{1 0}$ (1.47 g, $95 \%$ yield). Analysis by capillary gas chromatography (isotherm, $\left.125^{\circ} \mathrm{C}\right)$ showed $2\left(t_{R}=11.06 \mathrm{~min}, 36 \%\right)$ and $10\left(t_{R}=17.70 \mathrm{~min}\right.$, $64 \%$ ) as determined by GC standards. HRMS for $2 \mathrm{C}_{10} \mathrm{H}_{13} \mathrm{~N}_{1}\left(\mathrm{M}^{+}+\mathrm{H}\right)$ calcd: 148.1121; found: 148.1093. HRMS for $10 \mathrm{C}_{10} \mathrm{H}_{15} \mathrm{~N}_{1} \mathrm{O}_{1}\left(\mathrm{M}^{+}+\mathrm{H}\right)$ calcd: 166.1220; found: 166.1226 .

Mixture of 1-phenyl-pyrrolidine (2) and 4-phenylamino-butan-1-ol (10). Reduction of 1phenyl-2-pyrrolidinone with lithium diisopropylaminoborohydride at $65^{\circ} \mathrm{C}$ (5 mmol scale). Clear, colorless oil as mixture of 2 and $\mathbf{1 0}(0.651 \mathrm{~g}, 85 \%$ isolated yield). Analysis by capillary gas chromatography (isotherm, $\left.125{ }^{\circ} \mathrm{C}\right)$ showed $2\left(t_{R}=11.06 \mathrm{~min}, 50 \%\right)$ and $10\left(t_{R}=17.70\right.$ min, $50 \%)$ as determined by GC standards. HRMS for $2 \mathrm{C}_{10} \mathrm{H}_{13} \mathrm{~N}_{1}\left(\mathrm{M}^{+}+\mathrm{H}\right)$ calcd: 148.1121; found: 148.1093. HRMS for $10 \mathrm{C}_{10} \mathrm{H}_{15} \mathrm{~N}_{1} \mathrm{O}_{1}\left(\mathrm{M}^{+}+\mathrm{H}\right)$ calcd: 166.1220; found: 166.1226.

1-Benzyl-4-hydroxymethyl-pyrrolidin-2-one (12). Procedure for reduction of 1-benzyl-5-oxopyrrolidine-3-carboxylic acid methyl ester with lithium dimethylaminoborohydride at $-10{ }^{\circ} \mathrm{C}$ ( 5 mmol scale). A dry $100-\mathrm{mL}$ RB flask with sidearm fitted with a water-cooled reflux condenser, magnetic stirring bar and rubber septum was flushed with nitrogen gas. At $-10^{\circ} \mathrm{C}$, the flask was charged with a THF solution of lithium dimethylaminoborohydride $(5.5 \mathrm{~mL}, 1 \mathrm{M}$, $5.5 \mathrm{mmol}$ ) and methyl 1-benzyl-2-oxo-pyrrolidine-4-carboxylate $(1.17 \mathrm{~g}, 5 \mathrm{mmol})$. The reaction was stirred at $-10^{\circ} \mathrm{C}$. After stirring at $-10{ }^{\circ} \mathrm{C}$ for $2 \mathrm{~h}$, an aliquot was taken and analyzed by FTIR 
spectroscopy. FTIR analysis (THF, $\mathrm{cm}^{-1}$ ) showed the disappearance of the ester carbonyl peak at $v=1736 \mathrm{~cm}^{-1}$. After $2 \mathrm{~h} \mathrm{at}-10^{\circ} \mathrm{C}$, the reaction was quenched with $15 \mathrm{~mL}$ of $3 \mathrm{M} \mathrm{HCl}$ (Caution: Hydrogen Evolution!). The aqueous layer was extracted with $4 \times 20 \mathrm{~mL}$ portions of $\mathrm{Et}_{2} \mathrm{O}$. The organic layers were combined, dried over anhydrous $\mathrm{MgSO}_{4}$, and filtered. The solvent was removed under vacuum $\left(35^{\circ} \mathrm{C}, 30\right.$ Torr $)$, and then $\left(25^{\circ} \mathrm{C}, 1\right.$ Torr $)$ to give $0.932 \mathrm{~g}$ ( $96 \%$ yield) of 12 as a viscous, light yellow oil, bp =200-202 ${ }^{\circ} \mathrm{C} @ 0.3$ Torr. ${ }^{1} \mathrm{H}-\mathrm{NMR}\left(500 \mathrm{MHz}, \mathrm{CDCl}_{3}\right)$ $\delta=2.25-2.46(\mathrm{dq}, 1 \mathrm{H}, \mathrm{J}=5 \mathrm{~Hz}), 2.48-2.52(\mathrm{~m}, 1 \mathrm{H}), 2.53-2.56(\mathrm{t}, 2 \mathrm{H}, \mathrm{J}=9 \mathrm{~Hz}), 3.08-3.11(\mathrm{dd}$, $1 \mathrm{H}, \mathrm{J}=6 \mathrm{~Hz}, \mathrm{~J}=10 \mathrm{~Hz}), 3.33-3.36(\mathrm{dd}, 1 \mathrm{H}, \mathrm{J}=9 \mathrm{~Hz}, \mathrm{~J}=10 \mathrm{~Hz}), 3.48-3.57(\mathrm{dq}, 2 \mathrm{H}, \mathrm{J}=6 \mathrm{~Hz})$, 4.36-4.46 (q, $2 \mathrm{H}, \mathrm{J}=15 \mathrm{~Hz}$ ), 7.22-7.23 (dt, $2 \mathrm{H}, \mathrm{J}=2 \mathrm{~Hz}, \mathrm{~J}=6 \mathrm{~Hz}), 7.25-7.28$ (tt, $1 \mathrm{H}, \mathrm{J}=2 \mathrm{~Hz}, \mathrm{~J}$ $=8 \mathrm{~Hz}), 7.29-7.33(\mathrm{tt}, 3 \mathrm{H}, \mathrm{J}=2 \mathrm{~Hz}, \mathrm{~J}=8 \mathrm{~Hz}) .{ }^{13} \mathrm{C}-\mathrm{NMR}\left(125 \mathrm{MHz}, \mathrm{CDCl}_{3}\right) \delta=33.29,34.10$, $46.72,49.42,64.68,127.74,128.22,128.82,136.37,174.24$. FTIR $\left(\mathrm{THF}, \mathrm{cm}^{-1}\right) v=1667(\mathrm{st} \mathrm{C}=\mathrm{O}$ lactam). HRMS for $\mathrm{C}_{12} \mathrm{H}_{15} \mathrm{~N}_{1} \mathrm{O}_{2}\left(\mathrm{M}^{+}+\mathrm{H}\right)$ calcd: 206.1176; found: 206.1203 .

(1-Benzyl-4-pyrrolidin-3-yl)-methanol (13). Reduction of 1-benzyl-5-oxo-pyrrolidine-3carboxylic acid methyl ester with lithium dimethylaminoborohydride at $65^{\circ} \mathrm{C}(5 \mathrm{mmol} \mathrm{scale})$. A dry 100-mL RB flask with sidearm fitted with a water-cooled reflux condenser, magnetic stir bar and rubber septum was flushed with nitrogen gas. At $0{ }^{\circ} \mathrm{C}$, the flask was charged with a THF solution of lithium dimethylaminoborohydride $(12.5 \mathrm{~mL}, 1 \mathrm{M}, 12.5 \mathrm{mmol})$ and 1-benzyl-5-oxopyrrolidine-3-carboxylic acid methyl ester $(1.17 \mathrm{~g}, 5 \mathrm{mmol})$. The reaction mixture was heated to reflux $\left(65^{\circ} \mathrm{C}\right)$. After stirring at $65{ }^{\circ} \mathrm{C}$ for $2 \mathrm{~h}$, an aliquot was taken and analyzed by FTIR spectroscopy. FTIR analysis (THF, $\mathrm{cm}^{-1}$ ) showed the disappearance of the lactam carbonyl peak at $v=1690 \mathrm{~cm}^{-1}$ and the ester carbonyl peak at $v=1736 \mathrm{~cm}^{-1}$. After $2 \mathrm{~h}$, the reaction mixture was cooled under nitrogen gas to $0{ }^{\circ} \mathrm{C}$ and the reaction was quenched with $25 \mathrm{~mL}$ of $3 \mathrm{M} \mathrm{HCl}$ (Caution: Hydrogen Evolution!). The aqueous layer was extracted with $4 \times 20 \mathrm{~mL}$ portions of $\mathrm{Et}_{2} \mathrm{O}$. At $0{ }^{\circ} \mathrm{C}$, solid $\mathrm{NaOH}$ was added to aqueous layer until strongly basic $(\mathrm{pH}=12)$ to litmus. The aqueous layer was extracted with 4 x $20 \mathrm{~mL}$ portions of $\mathrm{THF} / \mathrm{Et}_{2} \mathrm{O}$. The organic layers were combined, dried over anhydrous $\mathrm{MgSO}_{4}$, and filtered. The solvent was removed under vacuum ( $35{ }^{\circ} \mathrm{C}$, 30 Torr), and then $\left(25^{\circ} \mathrm{C}, 1\right.$ Torr $)$ to give $0.845 \mathrm{~g}(88 \%$ yield $)$ of $13\left(\mathrm{C}_{12} \mathrm{H}_{17} \mathrm{~N}_{1} \mathrm{O}_{1}\right.$, MW $=192 \mathrm{~g} / \mathrm{mol})$ as a clear, viscous yellow oil. ${ }^{1} \mathrm{HNMR}\left(500 \mathrm{MHz}, \mathrm{CDCl}_{3}\right) \delta=1.67-1.74(\mathrm{~m}, 1 \mathrm{H}, \mathrm{J}=$ $4 \mathrm{~Hz}), 1.98-2.05(\mathrm{~m}, 1 \mathrm{H}, \mathrm{J}=4 \mathrm{~Hz}), 2.32-2.38(\mathrm{~m}, 2 \mathrm{H}, \mathrm{J}=2 \mathrm{~Hz}), 2.52-2.64(\mathrm{dq}, 2 \mathrm{H}, \mathrm{J}=7 \mathrm{~Hz})$, 2.79-2.84 (sextet, $1 \mathrm{H}, \mathrm{J}=5 \mathrm{~Hz}$ ), 3.51-3.68 (dq, $2 \mathrm{H}, \mathrm{J}=5 \mathrm{~Hz}), 3.61(\mathrm{~s}, 2 \mathrm{H}), 7.24-7.34(\mathrm{~m}, 5 \mathrm{H})$. ${ }^{13} \mathrm{C}-\mathrm{NMR}\left(125 \mathrm{MHz}, \mathrm{CDCl}_{3}\right) \delta=27.10,38.92,53.84,58.27,60.31,67.61,127.16,127.44$, 128.87, 138.8. HRMS for $\mathrm{C}_{12} \mathrm{H}_{17} \mathrm{~N}_{1} \mathrm{O}_{1}(\mathrm{M})^{+}$calcd: 192.1383; found: 192.1403 .

\section{Acknowledgments}

This paper is dedicated to Professor Alfred Hassner for his many contributions to the field of Chemistry. The authors would like to thank Callery Chemical Company for supplying 9-BBN, borane-dimethylsulfide and dimethylamine-borane used in this research and the generous donors of the Petroleum Research Fund. Special thanks to Dr. RuAn Edrada for training on the Applied 
BioSystems Mariner Mass Spectrometer.

\section{References and Notes}

1. Tao, X.; Nishiyama, S.; Yamamura, S. Chem. Lett. 1991, 1785.

2. Winterfeldt, E. Synthesis 1975, 617.

3. Brown, H. C.; Yoon, N. M. J. Am. Chem. Soc. 1966, 88, 1464. (b) Yoon, N. M.; Brown, H. C. J. Am. Chem. Soc. 1968, 90, 2927. (c) Yasuda, S.; Hirasawa, T.; Yoshida, H.; Hanaoka, M. Chem. Pharm. Bull. 1989, 37, 1682.

4. Cannon, J. G.; Chang, Y.; Amoo, V. E.; Walker, K. A. Synth. Comm. 1986, 494.

5. Kuwano, R.; Takahashi, M.; Ito, Y. Tetrahedron Lett. 1998, 39, 1017.

6. (a) Umino, N.; Iwakuma, T.; Itoh, N. Tetrahedron Lett. 1976, 10, 763. (b) Tabusa, F.; Miyamoto, H.; Kano, M.; Ueda, Tamaoka, H.; Nakagawa, K. Chem. Pharm. Bull. 1989, 37, 2103.

7. (a) Smith, P. A. S.; Yu, T. J. Am. Chem. Soc. 1952, 74, 1096. (b) Luo, Y.; Yu, Q.; Chrisey, L.; Brossi, A. Heterocycles 1990, 31, 283. (c) Gaylord, N. G. Reduction with Complex Metal Hydrides; Interscience Publishers, Inc.: New York, 1956; p. 545-642. (d) Meyers, A. I.; Berney, D. J. Org. Chem. 1989, 54, 4673. (e) Smidrkal, J.; Holubek, J.; Trojanek, J. Collect. Czech. Chem. Commun. 1985, 50, 984. (f) Larock, R. C. Comprehensive Organic Transformations; VCH Publishers: New York, 1989; pp 432-434 and references cited therein. (g) Challis, B. C.; Challis, J. A. The Chemistry of Amides J. Zabicky Ed.; Interscience Publishers: New York, 1970; pp 795-801.

8. (a) Sirowej, H.; Khan, S. A.; Pleninger, H. Synth. Comm. 1971, 1, 84. (b) Brown, H. C.; Heim, P. J. Org. Chem. 1973, 38, 912. (c) Kornet, M. J.; Thio, P. A.; Tan, A. S. J. Org. Chem. 1968, 33, 3637.

9. Block, J.; Gray, H. P. Inorg. Chem. 1965, 4, 304.

10. (a) Fisher, G. B.; Fuller, J. C.; Harrison, J.; Goralski, C. T.; Singaram, B. Tetrahedron Lett. 1993, 34, 1091. (b) Fisher, G. B.; Fuller, J. C.; Harrison, J.; Alvarez, S. G.; Burkhardt, E. R.; Goralski, C. T.; Singaram, B. J. Org. Chem. 1994, 59, 6378. (c) Flaniken, J. M.; Collins, C. J.; Lanz, M.; Singaram, B. Org. Lett. 1999, 1, 799.

11. (a) Brown, H. C.; Chen, J. C. J. Org. Chem. 1981, 46, 3978. (b) Brown, H. C.; Krishnamurthy, S.; Yoon, N. M. J. Org. Chem. 1976, 41, 1778. (c) Meyers, A. I.; Andres, C. J.; Resek, J. E.; McLaughlin, M. A.; Woodall, C. C.; Lee, P. H. J. Org. Chem. 1996, 61, 2586. (d) Meyers, A. I.; Andres, C. J.; Resek, J. E.; McLaughlin, M. A.; Woodall, C. C.; Lee, P. H.; Price, D. A. Tetrahedron 1999, 55, 8931. (e) Godjoian, G.; Singaram, B. Tetrahedron Lett. 1997, 38, 1717. (f) Collins, C. J.; Lanz, M.; Singaram, B. Tetrahedron Lett. 1999, 40, 3673.

12. Keusenkothen, P. F.; Smith, M. B. Synth. Comm. 1989, 19, 2859. 